\title{
4140: Mass trapping and new toxic bait formulations for fruit fly management
}

\author{
Friday, September 30, 2016 \\ 02:45 PM - 03:00 PM \\ $\bigcirc$ Convention Center - Room W331 B
}

Introduction: Brazil is the third largest fruit producing country in the world, with fruit being grown at ca $2.8 \mathrm{mi}$ ha. The complex of fruit flies including South American fruit fly Anastrepha fraterculus and the Mediteranean fruit fly Ceratitis capitata are one of the most important insect pests of tropical and temperate fruit. Additionally, another fruit fly, the Bactrocera carambolaeis a new quarantine pest under official restrictions in the northern region of Brazil. Fruit flies are commonly managed by multiple applications of phosphorous insecticides, however this particular group of insecticides faces multiple restrictions related to the high toxicity of active ingredients to environment and poses risk to human health.

Methods: In this presentation we discuss the recent advances in the field applications of mass trapping system using hydrolyzed protein (Ceratrap ${ }^{\circledR}$ ) for fruit fly control in orchards. We also show results related to new toxic bait formulations which are more resistant to rainfall and with lower toxicity against parasitoids (Braconidae) and honey bee Apis melifera. These toxic bait formulations are based on wax $\left(\right.$ Anamed $^{\circledR}$ ) or gel (Gelsura ${ }^{\circledR}$ ) and are considered as effective alternatives to the insecticide spinosad $\left(\right.$ Success $\left.^{\circledR}\right)$ and hydrolyzed proteins formulated at the farm level by growers.

Results/Conclusion: Our results demonstrated that using mass trapping and new toxic bait formulations greatly improved the management of fruit flies, however, the successful control of fruit fly is still mostly dependent on the integration of various techniques such as cultural control and applications of neonicotinoid, pyretroid or spinosin based insecticides.

doi: 10.1603/ICE.2016.94448

\section{Author}

\section{Marcos Botton}

Embrapa Grape and Wine

\section{View Related Events}

Symposium: 629 Symposium: Technological Innovations and Integrated Pest Management

Program: Symposium

Day: Friday, September 30, 2016 